\title{
Temperature and massive fish deaths in southern South America
}

\author{
M. Jimena GONZÁLEZ NAYA ${ }^{1,2}$, Luciana RAMÍREZ1,2, Sergio E. GÓMEZ ${ }^{1,2}$ \\ \& Roberto C. MENNI ${ }^{1,3}$
}

\begin{abstract}
${ }^{1}$ Consejo Nacional de Investigaciones Científicas y Técnicas (CONICET), Argentina. ${ }^{2}$ Museo Argentino de Ciencias Naturales. Av. A. Gallardo 470, C1405DJR Buenos Aires, Argentina. ${ }^{3}$ División Zoología Vertebrados, Museo de La Plata. Paseo del Bosque s/n, 1900 La Plata, Argentina
\end{abstract}

\begin{abstract}
Based on a compilation of data on massive fish deaths occurred in southern South America during the Twentieth Century, we assessed the importance of climatic variables on these phenomena. We found a strong relationship $\left(\mathrm{R}^{2}=0.68\right)$ between these massive fish deaths and the mean monthly air temperature. Along the annual temperature range there is a central range $\left(14.6^{\circ} \mathrm{C}\right.$ to $\left.20.0^{\circ} \mathrm{C}\right)$, where the probabilities that a fish community suffers massive deaths is very low. Its central point $\left(17.3^{\circ} \mathrm{C}\right)$ is very close to the mean annual value $\left(17.2^{\circ} \mathrm{C}\right)$ of air temperature variation. We considered this agreement as corroboration at community level of Pianka's theory on physiological optima. This relationship allows to monitoring the influence of climate changes, because the environmental variation and the zones of mortality and no mortality will change with predicted changes of the mean monthly values of air temperature.
\end{abstract}

Key words: environmental change, fish communities, freshwater fish, massive fish deaths, temperature, Argentina.

Resumen: Temperatura y mortandades masivas de peces en el sur de Sudamérica. Basado en la recopilación de datos de mortandades masivas de peces ocurridas en el sur de Sud América durante el Siglo XX, se evaluó la importancia de las variables climáticas en estos fenómenos. Se encontró una fuerte relación $\left(R^{2}=0,68\right)$ con la temperatura media mensual del aire. A lo largo del rango de temperaturas anuales hay un rango central $\left(14,6^{\circ} \mathrm{C}\right.$ a $\left.20,0^{\circ} \mathrm{C}\right)$ donde las probabilidades que una comunidad de peces sufra mortandades masivas son muy bajas. Su punto central $\left(17,3^{\circ} \mathrm{C}\right)$ es muy cercano al valor medio anual $\left(17,2^{\circ} \mathrm{C}\right)$ de la variación de temperatura del aire. Se considera esto como una corroboración a nivel de comunidad de la teoría del óptimo fisiológico de Pianka. Esta relación permite monitorear la influencia de los cambios climáticos, dado que la variación ambiental y las zonas de mortalidad y no mortalidad cambiarán con las variaciones predichas de los valores medios mensuales de la temperatura del aire.

Palabras clave: cambio ambiental, comunidades de peces, peces de agua dulce, mortandades masivas, temperatura, Argentina.

\section{INTRODUCTION}

Massive fish deaths are relatively common phenomena in central and northern parts of the Argentine territory and other parts of the world (AFS, 1992). Often, they are related with one or several climatic variables, and rarely they occur because of a single factor, such as cold (Freyre, 1967) or heat (Kangur et al., 2007).

In the Florida Península (UF, 2003) and Australia (Dawson, 2002), the lethal factor associated to high temperatures are the strongly seasonal rains that bring alochthonous material to water bodies and the decomposition of organic matter in that material provokes suddenly strong oxygen depletion. Though numerous causal factors are known, it is considered that temperature plays a fundamental role in these processes.

The massive fish deaths (MFD) considered in this paper affected both, lentic and lotic environments within an area measuring 1.4 million $\mathrm{km}^{2}$, ranging $1300 \mathrm{~km}$ along the north-south axis from the Iguazú Falls ( $25^{\circ} 41^{\prime} \mathrm{S}$ ) to the Dolores Pond ( $36^{\circ} 21^{\prime} \mathrm{S}$ ), and $1200 \mathrm{~km}$ along an east-west direction, from the Atlantic coast $\left(52^{\circ} 30^{\prime} \mathrm{W}\right)$ to the Río Tercero Dam (64 $\left.10^{\prime} \mathrm{W}\right)$. This area includes environments belonging to the Argentine section of the zoogeographic Guayano-Brazilian subre- 
gion (sensu Ringuelet, 1961). Fish species living in the area and susceptible to MFD are considered Paranoplatensean or Pampasic (Ringuelet, 1975), and their distribution and general ecology are discussed in Menni (2004).

Ecological theory establishes that "for each environmental variable there is a physiological optimum, where the biological efficiency of the organism is a maximum" (Pianka, 1983). This statement may be conceptually derived from principles referred to fishes under laboratory conditions (Fry, 1971) and it explains numerous situations. Notwithstanding, its application to concrete data is difficult, because of the different statistical distribution of environmental variables, and because the wide concept of "biological efficiency" only may be interpreted, for the time being, as survival, growth or reproduction. Here we examine MFD as related to the Pianka's statement on optimal values, obtaining a quantitative precise generalization related to environmental change.

\section{MATERIALS AND METHODS}

Sixty six MFD were examined from Argentina and southern Brazil, occurred between 1912 and 2007 ( $\mathrm{n}=25$ from Gómez (1996); $\mathrm{n}=19$ from MAA (2000) and $n=22$ from personal communications and personal observations, news reporting from the Argentinean newspapers Clarín, La Nación and El Día). These MFD were attributed to very different causes including heat (Gómez, 1986), cold (Freyre, 1967), toxic algae blooming (Colautti et al., 1998), hypoxia, toxic spills, management mistakes (Domitrovic et al., 1994) and organic matter excess.

For this analysis we used climatic statistics from 1961 to 1970, which is the first decade previous to the detection of global climatic change in Argentina (IPCC, 2002; Barros et al., 2006). Data were obtained from the meteorological station Aero Buenos Aires, placed at $6 \mathrm{~m}$. above sea level at $34^{\circ} 34^{\prime} \mathrm{S}$ and $58^{\circ} 25^{\prime} \mathrm{W}$ (SMN, 1985). This station is representative of the climate variation of the Paranense and Pampasic areas in the southern parts of the Guayano-Brazilian subregion.

\section{RESULTS}

MFD have been registered throughout the year except April. The relationships between the number of monthly MFD and the monthly oscillation of temperature $\left({ }^{\circ} \mathrm{C}\right)$, rainfall $(\mathrm{mm})$ and atmospheric pressure (mb) (Fig. 1) show that

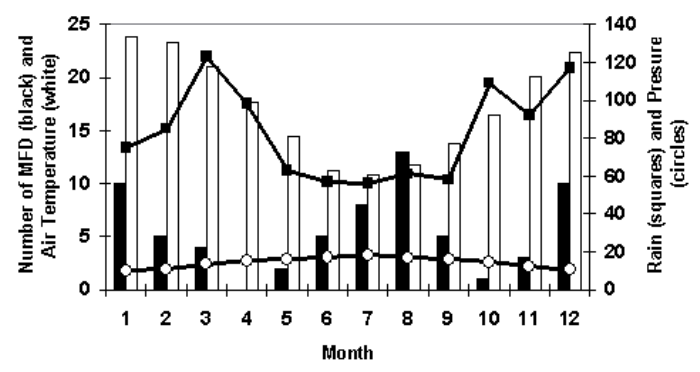

Fig. 1. Relationship between massive fish deaths (MFD) and climatic variables along the annual cycle during 95 years. Rainfall in $\mathrm{mm}$, air temperature in ${ }^{\circ} \mathrm{C}$ and pressure in $\mathrm{mb}-1000$.

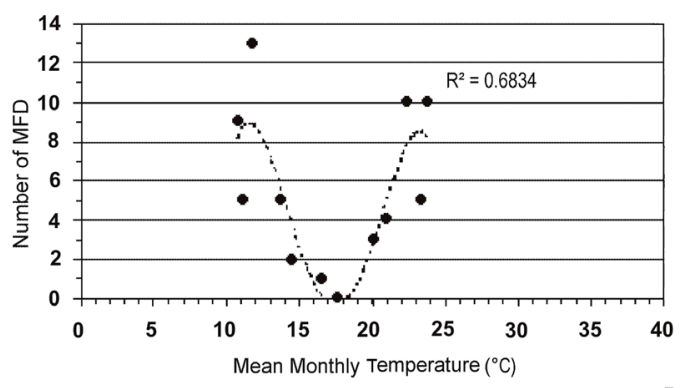

Fig. 2. Relationship between number of monthly massive fish deaths (MFD) (dotted line) and the mean monthly air temperature along 95 years.

MFD have a random distribution with respect to rainfall $(r=0.2795)$ and pressure $(r=0.1338)$, but they have an evident relationship (Pearson's coefficient) with the mean monthly air temperature (MMT) observations in spring and summer $(\mathrm{r}=0.6056, \mathrm{p}<0.05)$, and in autumn and winter $(\mathrm{r}=-0.5801, \mathrm{p}<0.05)$.

MFD are more frequent in summer and winter. If the same data are represented as the absolute frequency of MFD in relation with the mean monthly air temperature (MMT) corresponding to the month of occurrence along to 95 years of observations (Fig. 2), the data fit a bell-shaped curve that shows the occurrence of more than one MFD within the range below $14.5^{\circ} \mathrm{C}$ and over $20.1^{\circ} \mathrm{C}$. This curve has a high determination coefficient $\left(R^{2}=0.68\right)$, with more than $65 \%$ of the variance of the number of MFD explained by the variation of MMT.

A zone of no mortality (NMZ) corresponds to the temperature ranging from $14.6^{\circ} \mathrm{C}$ to $20.0^{\circ} \mathrm{C}$, with a central point at $17.3^{\circ} \mathrm{C}$. This point is a physiological optimum (PO), where species have a maximum of efficiency and where the probability of suffering a MFD due to temperature is very low.

For the bulk of Paranensean and Pampasic fis- 


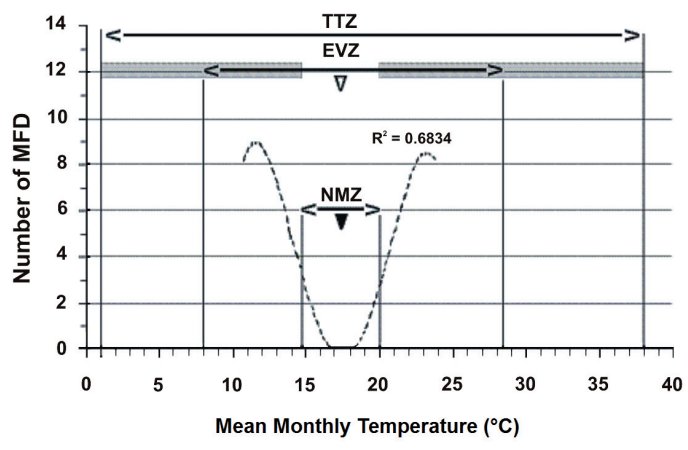

Fig. 3. Thermal zones: Relationship between monthly number of MFD and mean monthly temperatures (see Fig. 2). TTZ: thermal tolerance zone $\left(1^{\circ} \mathrm{C}\right.$ to $\left.38^{\circ} \mathrm{C}\right)$. EVZ: environmental variation zone of air temperature $\left(18^{\circ} \mathrm{C}\right.$ to $28^{\circ} \mathrm{C}$, the white triangle is the mean value $\left.17.2^{\circ} \mathrm{C}\right)$. NMZ: non mortality zone $\left(14.6^{\circ} \mathrm{C}\right.$ to $20^{\circ} \mathrm{C}$, the triangle is the physiological optimum $17.3^{\circ} \mathrm{C}=$ PO). Grey zones: temperature values associated to death $\left(1^{\circ} \mathrm{C}\right.$ to $14.6^{\circ} \mathrm{C}$ and $20^{\circ} \mathrm{C}$ to $\left.38^{\circ} \mathrm{C}\right)$.

hes, the thermal tolerance zone (TTZ) measured in laboratory has a range between $1^{\circ} \mathrm{C}$ to $38^{\circ} \mathrm{C}$ (Gómez, 1996). The environmental variation (EV) is less, ranging from $8.0^{\circ} \mathrm{C}$ to $28.4^{\circ} \mathrm{C}$ (SMN, 1985), with a mean annual value of $17.2^{\circ} \mathrm{C}$.

\section{DISCUSSION}

The NMZ here calculated based on field data $\left(14.6^{\circ} \mathrm{C}\right.$ to $\left.20.0^{\circ} \mathrm{C}\right)$ is included within the $\mathrm{TTZ}$ measured in laboratory $\left(1^{\circ} \mathrm{C}\right.$ to $\left.38^{\circ} \mathrm{C}\right)$. The difference between these intervals $\left(1.0^{\circ} \mathrm{C}\right.$ to $14.6^{\circ} \mathrm{C}$ and $20.0^{\circ} \mathrm{C}$ to $38^{\circ} \mathrm{C}$ ) is a range where temperature is an important factor associated with death. For example, a temperature of $8^{\circ} \mathrm{C}$ is not directly lethal, but fishes become weak and developed pathologies due to chronic exposure to sublethal levels, which brings them to death. At the other extreme, a non lethal temperature of $32^{\circ} \mathrm{C}$ increases metabolism and accelerates oxygenconsuming degradation of organic matter, finally causing fish death by asphyxia.

Usually, the optimal values of a variable for a given species are obtained from individuals under experimental conditions. Here, we use an indirect reasoning based on the range where massive deaths occur, implying communities or part of them, to validate and to extend Pianka's theory. MFD and temperature data are, in this case, independent in space and time.

The calculated physiological optimum of temperature $\left(\mathrm{PO}=17.3^{\circ} \mathrm{C}\right)$ does not present significant differences $(\mathrm{p}<0.005$, two-tailed $\mathrm{T}$ test; $\mathrm{t}=-0.019795 ; \mathrm{p}=0.978648$ ) with the mean annual value of the environmental variation of air temperature $\left(17.2^{\circ} \mathrm{C}\right)$ of the environments inhabited by the considered species in the studied area (Fig. 3). During the last 40 years in the Salado Basin in Argentina ( $\left.36^{\circ} \mathrm{S}\right)$, the mean minimum annual temperature have risen from $8.9^{\circ} \mathrm{C}$ to $10.1^{\circ} \mathrm{C}$ and the total annual rainfall have increased from 700 to $950 \mathrm{~mm}$ (Gómez \& Menni, 2005). These changes have resulted in the formation of new fish communities in water bodies formed in previously dry areas (Gómez et al., 2004).

Temperature increase attributed to global change is considered one of the most important factors in producing changes in freshwater systems (Meisner \& Shuter, 1992; Gooseff et al., 2005; Ficke et al., 2007). Other factors such as the available amount of water, oxygen diminution and dryness should also be considered.

The generalization proposed here may be used to predict MFD and to assess the impact of climate change on freshwater fish communities, since the values of the NMZ and the EV will change along with changes of the mean monthly air temperature.

\section{ACKNOWLEDGMENTS}

The authors deeply thank the advice of L.O. Lucifora (Halifax University, Canada), M.L. García and M. Cuello (Museo de La Plata).

\section{BIBLIOGRAPHY}

A.F.S., American Fisheries Society. 1992. Investigation and valuation of fish kills. AFS Spec. Publ. N ${ }^{\circ} 24,1-96$.

Barros, V., R. Clark \& P. Silva Dias. 2006. El cambio climático en la Cuenca del Plat., pp. 1-260. CONICET, Buenos Aires.

Colautti, D.C., M. Remes Lenicov, N. Gómez \& C. Claps. 1998. Mortandad de peces en el arroyo San Miguel (Partido de Pila, Provincia de Buenos Aires). Gayana Zool. 62(2): 191-197.

Dawson, K. 2002. Fish kill events and habitat losses of the Richmond River, NSW Australia: an overview. J. Coast Res. 36: 216-221.

Domitrovic, H.A., J.A. Bechara, R.W. Jacob, C.I. Flores Quintana \& J.P. Roux. 1994. Mortandad de peces en el Río Paraná provocada por una sobresaturación de gases: causas y lesiones. Rev. Ictiol. 2-3: 49-54.

Ficke, A.D., C.A. Myrick \& L.J. Hansen. 2007. Potential impacts of global climate change on freshwater fisheries. Rev. Fish Biol Fish. 17: 581-613.

Freyre, L.R. 1967. Consecuencias de la mortalidad de peces por las temperaturas extremas de junio de 1967 en laguna Chascomús. Agro 9: 35-47.

Fry, F.E.J. 1971. Effects of environmental factors on the physiology of fish. En: W.S. Hoar \& D.J. Randall 
(Eds.), Fish Physiology 6: 1-97, Academic Press, New York.

Gómez, S.E. 1986. Mortandad de peces por acción del calor en el río Iguazú (Misiones, Argentina). Spheniscus 4: 25-30.

Gómez, S.E. 1996. Resistenza alla temperatura e salinitá in pesci della Provincia di Buenos Aires (Argentina), con implicazioni zoogeografiche. En: Atti Congressuali IV Convegno Nazionale Associazione Italiana Ittiologi Acque Dolci 1991, pp. 171-192, AIIAD, Trento, Italia.

Gómez, S.E. \& R.C. Menni. 2005. Cambio ambiental y desplazamiento de la ictiofauna en el Oeste de la Pampasia (Argentina Central). Biología Acuática 22: 151-156.

Gómez, S.E., P.S. Trenti \& R.C. Menni. 2004. New fish populations as evidence of climate change in former dry areas of the Pampa Region (Southern South America). Physis B 59: 43-44.

Gooseff, M.N., K. Strzepek \& S.C. Chapra. 2005. Modeling the potential effects of climate change on water temperature downstream of a shallow reservoir, lower Madison River, MT. Clim. Chang. 68: 331-353.

I.P.C.C., Intergovernmental Panel on Climate Change. 2002. Third Assessment Report. The Scientific Basis. Cambridge University Press.

Kangur, A., P. Kangur, K. Kangur \& T. Möls. 2007. The role of temperature in the population dynamics of smelt Osmerus eperlanus eperlanus $m$. spirinchus Pallas in Lake Peipsi (Estonia/Russia). Hydrobiología 584: 433-441.

M.A.A., Ministerio de asuntos Agrarios de la Provincia de Buenos Aires. 2000. Mortandad de peces en aguas continentales de la provincia de Buenos Aires. Informe técnico, División de Desarrollo pesquero, Subsecretaría de Actividades Pesqueras, 6 p.

Meisner, J.D. \& B.J. Shuter. 1992. Assessing potential effects of global climate change on tropical freshwater fishes. Geoj. 28: 21-27.

Menni, R.C. 2004. Peces y ambientes en la Argentina continental. Monografías del Museo Argentino de Ciencias Naturales, 5, Buenos Aires, 316 pp.

Pianka, E.R. 1983. Evolutionary Ecology. $3^{\text {rd }}$ edn, Harper and Row, New York, 416 pp.

Ringuelet, R.A. 1961. Rasgos fundamentales de la zoogeografía de la Argentina. Physis 22: 151-170.

Ringuelet, R.A. 1975. Zoogeografía y ecología de los peces de aguas continentales de la Argentina y consideraciones sobre las áreas ictiológicas de América del Sur. Ecosur, 2: 1-122.

S.M.N., Servicio Meteorológico Nacional. 1985. Estadísticas Climatológicas 1961-1970. Fuerza Aérea Argentina, Publicación № 35, Buenos Aires, $188 \mathrm{pp}$.

U.F., University of Florida. 2003. Understanding fish kills in Florida freshwater system. A Benniger's Guide to Water Management, Fish Kills, Inform. Circ. 107: 1-16. 